\title{
An optimized scheme of lettered marine isotope substages for the last 1.0 million years, and the climatostratigraphic nature of isotope stages and substages
}

\author{
Railsback L. Bruce ${ }^{1,{ }^{*}}$, Gibbard Philip L. ${ }^{2}$, Head Martin J. ${ }^{3}$, Voarintsoa Ny Riavo G. ${ }^{1}$, \\ Toucanne Samuel ${ }^{4}$
}

${ }^{1}$ Department of Geology, University of Georgia, Athens, GA 30602-2501, USA

${ }^{2}$ Department of Geography, University of Cambridge, Downing Street, Cambridge CB2 3EN, England, UK

${ }^{3}$ Department of Earth Sciences, Brock University, 500 Glenridge Avenue, St. Catharines, Ontario L2S

3A1, Canada

${ }^{4}$ IFREMER, Laboratoire Environnements Sédimentaires, BP70, 29280 Plouzané, France

* Corresponding author : L. Bruce Railsback, Tel.: +1 706542 3453; fax: +1 7065422652 ;

email address : rlsbk@gly.uga.edu

\begin{abstract}
:
A complete and optimized scheme of lettered marine isotope substages spanning the last 1.0 million years is proposed. Lettered substages for Marine Isotope Stage (MIS) 5 were explicitly defined by Shackleton (1969), but analogous substages before or after MIS 5 have not been coherently defined. Short-term discrete events in the isotopic record were defined in the 1980 s and given decimal-style numbers, rather than letters, but unlike substages they were neither intended nor suited to identify contiguous intervals of time. Substages for time outside MIS 5 have been lettered, or in some cases numbered, piecemeal and with conflicting designations. We therefore propose a system of lettered substages that is complete, without missing substages, and optimized to match previous published usage to the maximum extent possible. Our goal is to provide order and unity to a taxonomy and nomenclature that has developed ad hoc and somewhat chaotically over the decades. Our system is defined relative to the LR04 stack of marine benthic oxygen isotope records, and thus it is grounded in a continuous record responsive largely to changes in ice volume that are inherently global. This system is intended specifically for marine oxygen isotope stages, but it has relevance also for oxygen isotope stages recognized in time-series of non-marine oxygen isotope data, and more generally for climatic stages, which are recognized in time-series of non-isotopic as well as isotopic data. The terms "stage" and "substage" in this context are best considered to represent climatostratigraphic units, and thus "climatic stages" and "climatic substages", because they are recognized from geochemical and sedimentary responses to climate change that may not have been synchronous at global scale.
\end{abstract}




\section{Highlights}

- We define lettered MIS substages for past 1.0 million years relative to LRO4. Contradictions and gaps exist among previous ad-hoc designations of substages. Many marine isotope substages have been defined relative to non-marine records. This scheme of substages is complete and maximally consistent with earlier efforts. Marine isotope stages and substages are climatostratigraphic, not geochronologic.

Keywords: Substages, Stages, Marine isotope stages, MIS, Chronology, Chronostratigraphy, Climatostratigraphy 


\section{Introduction}

As the complex history of Quaternary glaciation, climate, sea level, and ocean circulation

51 has become apparent over the past 60 years, the scientific community has developed a variety of

52 systems to identify intervals of time and glacio-climatic events. One of the most widely applied

53 systems has been that of numbered marine oxygen isotope stages, or more generally oxygen

54 isotope stages, moving from the Holocene back in time as MIS 1, MIS 2, MIS 3, etc., where

55 "MIS" refers to "marine isotope stage". These isotope stages have been divided in some cases

56 into lettered substages, most notably in MIS 5 as substages MIS 5a, 5b, 5c, 5d, and 5e, which

57 were formally defined as such by Shackleton (1969). In the past 20 years, many publications

58 have used lettered substages for intervals outside MIS 5, from MIS 2a (Yelovicheva, 2006) to at

59 least MIS 19c (Tzedakis et al., 2012a,b). However, these lettered substages other than those of

60 MIS 5 have been named in many different papers, in no coherent system, and sometimes with

61 conflicting designations of substages. Further, these lettered substages denoting intervals of time

62 are commonly interwoven if not confused with a numbered system that was formulated to

63 identify events rather than intervals, as discussed below. As a result, researchers are left with an

64 inconsistent and sometimes conflicting nomenclature originating in a diverse and scattered

65 literature.

66 In light of the usefulness of isotope stages and lettered substages, but also the piecemeal

67 origin and disarray of the substage nomenclature, we review the origins of Quaternary isotope

68 chronological schemes and tabulate the earliest reports of the lettered isotope substages. We then

69 present a scheme of lettered isotope substages consistent with the previous scattered designations

70 that have appeared in the literature, with the hope that this scheme can avoid further

71 contradictions and provide a single unified source for future researchers. This scheme is defined

72 relative to the LR04 stack of marine benthic oxygen isotope records, a continuous record that

73 largely represents changes in ice volume that are inherently global and thus useful for global

74 correlation. 


\section{2. Evolving concepts of stages and events}

\section{2.1. Named continental stages and substages (before 1940)}

78 The concept of stages as deposits representing intervals of time, which are formally 79 known as "ages" (Salvador, 1994), in Pleistocene history (e.g., Cohen et al. 2013) derives

80 from named stages, such as Wisconsin and Kansan (Geikie, 1894; Chamberlin 1895) (Table

81 1). Those stages were defined by climatically significant continental deposits, rather than by

82 faunal zones, in the peculiarly Quaternary paradigm (Flint, 1947, p. 209) now known as

83 “climatostratigraphy" (Mangerud et al., 1974; Harland, 1992; Gibbard, 2014). More recent

84 North American stages had named substages, such as the Iowan, Tazewell, Cary, and Mankato 85 substages of the Wisconsin (Leighton, 1933).

\subsection{Numbered marine stages, and their substages (1952-1969)}

88 The more recent concept of numbered and marine, rather than named and continental,

89 climatostratigraphic stages arose with the work of Arrhenius (1952). In plotting the concentration

90 of $\mathrm{CaCO}_{3}$ in marine sediment cores, Arrhenius (1952) made correlations using stages and

91 substages numbered in decimal style, with the uppermost and therefore most recent stage

92 designated "1" and followed by "2', "3.1", 3.2", "4" and "5". Arrhenius (1952) recognized that

93 his odd-numbered stages represented interglacial periods and his even-numbered stages

94 represented glacial periods, and he thought it "probable" that his youngest four glacial stages

95 corresponded to the Nebraskan, Kansan, Illinoian, and Wisconsin "Ice Ages" (Arrhenius 1952, p.

96 200). His Fig. 3.4.2 recognized 18 stages over the last 1.0 million years, which was then

97 considered the entirety of the Pleistocene. Today, more stages are identified over both of those

98 intervals (e.g., Lisiecki and Raymo, 2005), but the system of stages generated by Arrhenius

99 (1952) provided a conceptual framework that was used when isotopic, rather than compositional,

100 analysis of marine cores (e.g., Emiliani, 1955) began soon after his work. Within that system, his 
101 stages numbered with integers clearly referred to intervals of sediment or time (e.g., in his Fig.

102 3.4.2), but his only illustration showing substages numbered in decimal style (his Fig. 1.2.4) used

103 lines pointing to peaks in his data, implying that these chronological features numbered in

104 decimal style were viewed as events as much as intervals (Fig. 1A), a distinction that would

105 become critical by the 1980 s.

106 Emiliani (1955), in characterizing the variability of his oxygen isotope data from deep-

107 sea cores, adopted the system of stages initiated by Arrhenius (1952). Emiliani (1955) recognized

10814 numbered "core stages" in his Figs. 3 and 15, in analogy to and for correlation with

109 continental glacial stages, as in his Table 15. Emiliani (1955) in some cases wrote about the

110 "thickness" of stages (his p. 554) and elsewhere used time terms (e.g., "preceded by" on his p.

111566 and "earlier” on his p. 557) to characterize stages. Emiliani’s Fig. 1 clearly labelled stages

112 with a time, rather than depth or thickness, axis. He thus made the transition from "stage" as a

113 term for sediments deposited during an interval of time to "stage" as a term for an interval of

114 time. The use of "stage" rather than "age" (Table 1) as a term for time in isotopic stratigraphy

115 has persisted, with implications discussed in Section 5.2.

116 Emiliani (1955) designated the present and previous interglacials as MIS 1, 5, 7, 9, 11,

117 etc., with MIS 3 as an interval that is no longer considered an interglacial (e.g., Sirocko et al.,

118 2007). That usage has persisted to the present, despite its imperfection as an arithmetic series,

119 and its persistence illustrates the extent to which the system of isotope stages is a matter of

120 consistent communication, rather than of contemporary geological reasoning. Its persistence as a

121 mathematically flawed but widely used chronological system is paralleled by the even more

122 widespread persistence of numbers used to identify years before (BCE) or after (CE) a datum

123 now acknowledged to have been misplaced by about five years (Teres, 1984; Maier, 1989). In

124 both cases, the need for consistency of usage has triumphed over logic and purity of system.

125 Emiliani (1955) designated no marine substages, despite explicitly noting continentally-

126 defined intervals such as the Allerød and Two Creeks that he called "substages". Emiliani (1961) 
127 followed his earlier publication (Emiliani, 1955) in recognizing 14 numbered stages in his Fig. 9,

128 and in his Fig. 10 he subdivided Stage 5 into five un-labelled intervals of isotopic maxima and

129 minima of lesser relative magnitude than those defining stages. Shackleton (1969) explicitly

130 labelled those five intervals as "isotope sub-stages" with letters "a" to "e" in his Fig. 1, and he

131 discussed "Substage 5e" extensively. Fig. 1 of Emiliani (1955) explicitly conceptualized stages

132 as intervals of time with boundaries at changes in temperature, and Fig. 10 of Emiliani (1961) and

133 Fig. 1 of Shackleton (1969) implicitly but clearly followed that model with substages as

134 successive contiguous intervals of time (Fig. 1B), in contrast to later schemes.

135 From the 14 isotope stages first recognized by Emiliani (1955), Emiliani (1966) extended

136 the system of isotope stages back to Stage 17 in his Fig. 6, and Shackleton and Opdyke (1973)

137 extended it to Stage 22 in their Fig. 9. Van Donk (1976) extended the system back to MIS 42 in

138 his Fig. 1, Ruddiman et al. (1989) extended the system of MIS stages to MIS 63 in their Fig. 7,

139 and Raymo et al. (1989) extended it from MIS 63 to MIS 116 in their Fig. 6 (but see also

140 Shackleton et al. 1990). Shackleton et al. (1995) extended the system back to the Miocene, and

141 thus to give a total of 220 marine isotope stages, in their Fig. 7. These stages beyond MIS 5e

142 were designated only with integers, and no substages were recognized, and thus neither letters nor

143 decimal-style numbers were used. Shackleton et al. (1995) did, however, remark that "lettered

144 substages" might eventually be useful in the early stages that they defined.

145 In the lineage from Arrhenius (1952) to Shackleton (1969) described above, a transition

146 was made from the non-isotopic substages with decimal-like numbers of the former to the lettered

147 isotopic substages of the latter. Shackleton (1969) cited Arrhenius (1952) but made no mention

148 of the numbered substages in that paper, leaving the previous use of decimal-style numbers by

149 Arrhenius seemingly forgotten, and thus leaving decimal-style numbers free for application to

150 isotopic "events" recognized in marine cores in the 1980s. 
153 Prell et al. (1986, p. 138) explicitly rejected the substage concept of Shackleton and

154 Opdyke (1973) because stages and substages, as intervals, were argued to not provide the distinct 155 control points needed to construct age models. Instead, Prell et al. (1986) used decimal-style 156 numbers to label "events", which were much briefer intervals at "maxima, minima, or rapid 157 changes" in the oxygen isotope record (Fig. 1C). The end of one event was commonly not the

158 beginning of the next, so that intervals of time between successive events were left without 159 designation. Numbers such as 2.0, 3.0, 4.0, etc., indicated boundaries, rather than intervals, and 160 they marked the boundaries of the isotope stages of Emiliani (1955).

161 Despite its publication date, Prell et al. (1986) was the cited source of systems used in 162 Imbrie et al. (1984) and Pisias et al. (1984). Imbrie et al. (1984) adopted a system of decimal163 style numbered "events", with boundaries at 2.0, 3.0, 4.0, etc., like that of Prell et al. (1986).

164 Pisias et al. (1984) used a similar series of decimal-style numbered "events" and cited Prell et al.

165 (1986) as a source, but they moved further from the model of Emiliani (1955), Imbrie et al.

166 (1984), and Prell et al. (1986) by using 1.0, 2.0, 3.0, etc. to label events that were intervals of non167 zero duration (Fig. 1D), rather than to label boundaries as Prell et al. (1986) had done.

168 Martinson (1987) cited Pisias et al. (1984) as the source of their system of decimal-style 169 numbered events. However, Fig. 18 of Martinson et al. (1987) suggests that each of that 170 publication's events, whether at transitions or at peaks or troughs, had no significant duration in 171 time (Fig. 1E), in contrast to the bracketed events of measurable duration shown by Prell et al.

172 (1986). Martinson et al. (1987) joined Pisias et al. (1984) in taking some decimal-style

173 designations to two places, as for example with Events 5.51 and 5.53 within Event 5.5 in Fig. 18

174 of Martinson et al. (1987). The series of publications from Prell et al. (1986) to Pisias et al.

175 (1984) and Imbrie et al. (1984) to Martinson et al. (1987) thus presents an evolving number-based

176 scheme of events, rather than contiguous intervals, different in intent and form from the lettered 177 substages of Shackleton (1969). 
178 Bassinot et al. (1994) continued this tradition by extending the system of numbered

179 events back to MIS 22 in their Fig. 7, and they maintained that tradition's focus on isolated peaks,

180 rather than on continuity of contiguous intervals, by not designating an Event 6.4 between their

181 Events 6.3 and 6.5, and likewise by not designating an Event 17.2 between their Events 17.1 and

182 17.3. Bassinot et al. (1994) consistently referred to integer-numbered stages (e.g., "Stage 19”),

183 decimal-style numbered events (e.g., "Isotopic Event 19.1”), and decimal-style numbered stage

184 boundaries (e.g., "Isotope stage boundary 23.0"), completely consistent with the conceptual

185 separation of lettered substages and decimal-style numbered events arising from the papers

186 discussed above. However, later workers would not maintain that distinction in using the

187 decimal-style numbers established by Bassinot et al. (1994).

\subsection{Hybridization and modification ( 1990 to present)}

Despite the distinction between stages and events established in the 1980s, later workers

191 have gone on to hybridize these schemes. For example, Plagnes et al. (2002), Wang et al. (2008),

192 Kitaba et al. (2011), and Muhs et al. (2014) used decimal-style numbers to one place to identify

193 substages, rather than events (Fig. 1F). Bühring et al. (2004) used decimal-style numbers to two

194 places to identify substages and drew these numbers from those used to identify events by Imbrie

195 et al. (1984) in some cases and by Martinson et al. (1987) in others. Poli et al. (2012) likewise

196 used decimal-style numbers to two places to identify substages, but they drew the numbers from

197 those used to identify events by Bassinot et al. (1994). In their text, Bühring et al. (2004)

198 innovated further by using substage designations with two decimal-style dots, as in their

199 substages 5.3.1 and 5.3.3. In a more complex hybrid, Jahns et al. (1998) combined decimal-style

200 numbers and letters in identifying single substages when they referred to " $\delta{ }^{18} \mathrm{O}$-substage $12.2 \mathrm{~h}$ ",

201 and Desprat et al. (2007) combined lettered and numbered substages (e.g, 8.2, 9e, and 11.3) in

202 one series in their Fig. 25.3.

203 Meanwhile, other workers challenged some of the original premises of earlier schemes. 
204 For example, Melles et al. (2007) and Vaks et al. (2010) extended the use of numbers with

205 Substage 6.1, and Melles et al. (2007) wrote of Substage 8.1, whereas none of the founding

206 papers of the 1960 s to 1990 s discussed above had referred to an event or substage 2.1, 4.1, 6.1, or

207 the like. That prior convention presumably prevailed because an even-numbered and therefore

208 glacial stage was not expected to end with a warm (odd-numbered) phase prior to a typically

209 abrupt termination.

211 2.5. Shackleton's valedictory perspective (2006) and beyond

212 Nicholas Shackleton (1937-2006) was the author of the first paper identifying lettered

213 isotope substages (Shackleton, 1969) and a co-author of the papers establishing the systems of

214 numbered events (Pisias et al., 1984; Imbrie et al., 1984; Prell et al., 1986; Martinson et al., 1987;

215 Bassinot et al. 1994), and a co-author on many of the works cited in Section 3 of this paper. In

216 his INQUA Presidential Address published as an "unfinished" paper in 2006, Shackleton

217 reiterated the difference between, on the one hand, substages representing bounded intervals that

218 collectively account for all of past time and, on the other hand, numbered events representing

219 points in time between which some intervals of time are undesignated (Shackleton, 2006). He

220 concluded that "the two systems are not interchangeable".

221 We concur that the two systems are not interchangeable, for two reasons. The first

222 reason, a conceptual one, is the contradiction above between contiguous intervals and discrete

223 events that was presented by Shackleton (2006) and that was implied in the explicit rejection of

224 stages and substages by Prell et al. (1986). The second reason, a practical one, is that the

225 assumption that the number "1" means "a", "2" means "b", etc., fails when one encounters an

226 interval numbered "X.0" (as in Wang et al., 2009 and Kitaba et al., 2011) because zero has no

227 analog among letters. Thus one cannot assume that "readers will know what we meant" when the

228 nomenclature of numbered events is applied to time intervals. In fact, the example from Fig. 8 of

229 Kitaba et al. (2011) is additionally instructive because that figure identifies two successive 
230 substages, 22.0 and 22.2, with no intervening 22.1, a designation compatible with the numbering

231 of events but incompatible with a succession of stages.

232 One recent and well-expressed example of the two systems can be seen in Figs. 3 to 6 of

233 Hernández-Almeida et al. (2012). These figures show the extent of MIS 20 to 30 in blue and

234 white bands between which there are no gaps, consistent with the notion of stages presented by

235 Emiliani (1955) and Shackleton and Opdyke (1973). The figures also show decimal-style

236 numbered events in red bands that are not contiguous. Events 24.1 and 29.1 are intervals of short

237 duration in the middles of MIS 24 and 29, respectively, and Event 30.1 is an event of short

238 duration at the beginning of MIS 30. The decimal-style numbered events are thus consistent with

239 the spirit of Pisias et al. (1984), Imbrie et al. (1984), Prell et al. (1986), and Martinson et al.

240 (1987) in marking isolated points in time. However, any attempt to convert these decimal-style

241 numbered events to substages would fail, because substages designated "1" or (more

242 appropriately) "a" should be at the end, rather than middles or beginnings, of the sequence of

243 substages in a stage.

245 3. Extension of lettered substages to time other than MIS 5, and resulting problems

246 In the last four decades, the system of lettered substages has been extended to time other

247 than Shackleton's (1969) MIS 5 substages (Table 2). However, that extension has been

248 accomplished largely in an ad-hoc fashion wherein lettered substages were denoted, but not

249 defined, in order to meet the needs of the subject matter of specific papers, some of which dealt

250 with terrestrial rather than marine deposits (Table 2). In some papers, substage designations were

251 used in figures but not mentioned in text, and in some cases substage designations were

252 mentioned in text but not illustrated in figures (e.g., Ninkovich and Shackleton, 1975). In almost

253 no cases were boundary lines between substages like those of Shackleton (1969) (Fig. 1B) drawn

254 on isotope time-series plots. Our compilation in Table 2 shows that the first occurrences, and in

255 some cases only occurrences, of use of these lettered substages outside MIS 5 are scattered across 
256 at least 19 papers. Despite this proliferation, some substages remain without explicit

257 identification amidst substages that have been labelled (e.g., Substages 13b and 16b).

258 In the midst of this piecemeal extension of lettered substages, contradictions have

259 developed (Fig. 2). Some examples, presented only to illustrate the hazards of this ad-hoc way of

260 creating a chronology, include the following:

261 1) Lundberg and MacFarlane (2007) designated three substages of MIS 6 (6c, 6b and 6a), and

262 they specifically defined MIS 6c as "the first cold period of MIS 6". On the other hand, Sun and

263 An (2005) discussed five substages of MIS 6 (6e, 6d, 6c, 6b and 6a), of which MIS 6e was the

264 earliest of three MIS 6 cold substages in their Fig. 7. Meanwhile, Kawamura et al. (2007)

265 designated five MIS 6 substages as MIS $6 \mathrm{f}, 6 \mathrm{e}, 6 \mathrm{~d}, 6 \mathrm{c}$ and $6 \mathrm{~b}$, with MIS $6 \mathrm{f}$ as the earliest cold

266 substage and no MIS 6a at all in their Figure 2, a usage later employed by Railsback et al. (2014).

267 2) Ninkovich and Shackleton (1975) designated the earliest substage of MIS 7 as MIS 7c, Bussell

268 and Pillans (1997) made the same designation (citing the decimal-style numbered events of

269 Imbrie et al. 1984 and Martinson et al. 1987 as their source), and Zazo (1999) similarly identified

270 MIS 7c and 7a as the two highstands of MIS 7, whereas Tzedakis et al. (1997) designated the

271 earliest substage of MIS 7 as MIS 7e, a usage subsequently followed by Schreve (2001),

272 Robinson et al. (2002), Siddall et al. (2007, their Table 7.1), and Compton (2011).

273 3) Bassinot et al. (1994) identified as Isotopic Event 8.5 the peak that Tzedakis et al. (1997)

274 designated as MIS 9a, a contradiction not only of substages but of stages.

275 4) Bussell and Pillans (1992), Bradley (1999, 2015), and Siddall et al. (2007) labelled the earliest

276 peak in MIS 9 as MIS 9c, whereas Tzedakis et al. (1997) designated that peak as MIS 9e, and it

277 was subsequently identified as MIS 9e on the Quaternary chronostratigraphical charts of Gibbard

278 and Cohen (2008) and Cohen and Gibbard (2011) and in Fig. 25.3 of Desprat et al. (2007). On

279 the other hand, Fig. 3 of Westaway (2011) presented a detailed series of substages from MIS 5a

280 to MIS 15e in which all of MIS 9 was labelled only "9" without subdivision.

281 5) Prokopenko et al. (2001) and Schreve (2001) referred to MIS 11e, and Ashton (2010) similarly 
282 referred to MIS 11d and MIS 11e, although Tzedakis et al. (1997) had defined MIS 11c as the

283 earliest substage of MIS 11. On the other hand, de Abreu et al. (2005) referred to MIS 7e and 9e,

284 evidently finding these lettered substages of use, in a paper focused on MIS 11 in which they

285 found no reason to refer to any substages of MIS 11 at all. Fig. 3 of Westaway (2011) likewise

286 presented a detailed series of substages from MIS 5a to MIS 15e in which all of MIS 11 was

287 labelled only "11" without subdivision.

288 6) Tzedakis et al. (2012a,b) labelled the earliest substage of MIS 15 as MIS 15c, whereas it had

289 been identified as MIS 15e by Khursevich et al. (2001) and Westaway (2011) and on the

290 Quaternary chronostratigraphical charts of Gibbard and Cohen (2008) and Cohen and Gibbard

291 (2011).

292 Meanwhile, attempts at numbered substages have fared no better. For example, Wang et

293 al. (2008) identified as Substage 7.0 the same interval that Bühring et al. (2004) designated as

294 MIS 6.6. Similarly, Vaks et al. (2010) identified the youngest substage of MIS 6 as MIS 6.1,

295 whereas Ruddiman (2006) had identified it as MIS 6.2. All eight examples combine to illustrate

296 the confusion that can arise when no single system exists to divide time series.

\section{4. A proposed system of lettered substages}

299 The long history of repeated attempts to label parts of Cenozoic time series at fine scale

300 shows that this is a useful and desirable component of communication about Earth history.

301 However, the piecemeal and ad-hoc approach to substages and its resultant contradictions (Fig. 2)

302 imply that a systematic development of substage taxonomy and nomenclature would be more

303 useful. We therefore propose the complete scheme of lettered substages shown in Fig. 3. Our

304 goals in preparing this scheme have included the following:

305 1) Definition of substages relative to a marine isotope record, rather than a terrestrial one. This

306 follows logically from the expression "Marine Isotope Stage", and it is consistent with the

307 objective of identifying time intervals that are meaningful at global, rather than regional, scale. 
308 Fig. 3 therefore shows three marine records, and its substages are defined relative to the LR04

309 stack of marine benthic oxygen isotope records of Lisiecki and Raymo (2005). However, Fig. 3

310 additionally includes four non-marine records that provide a basis for comparison with less

311 complete non-marine records from which some substages may be missing. The seven records in

312 Fig. 3 combine to provide depositional diversity (marine sediments, glacial ice, lacustrine silica

313 and pollen, and loess) and geographic diversity (Northern and Southern Hemispheres, and

314 Atlantic and Pacific). The records are also diverse in their applicability, in that the Lake Baikal

315 silica record of Propkopenko et al. (2006) characterizes substages of interglacial stages clearly,

316 whereas the Chinese loess record of Sun et al. (2006) conversely characterizes substages of

317 glacial stages clearly. Nonetheless, using benthic foraminiferal isotope records to define our

318 scheme means that it should substantially reflect global ice volume changes and therefore be

319 applicable across both hemispheres.

320 2) A scheme as consistent as possible with previous designations of substages, so as to minimize

321 conflict with the previous literature. This requires the following:

322 2a) Stages that end with a substage designated "a", and earlier substages are designated with

323 the sequence of letters of the Latin alphabet, consistent with the first lettered substages

324 defined by Shackleton (1969). This system precludes the interposition of additional

325 substages by later workers but avoids the confusion that would be inherent in a system with

326 missing letters that were subsequently inserted piecemeal.

327 2b) Substages that have been defined by their apparent paleoenvironmental significance, and

328 therefore by human inspection. One might argue for a scheme in which substages, and by

329 necessity stages as well, were identified by a mathematical or statistical algorithm, seemingly

330 independent of human judgment. Alternatively, one might argue for a theoretical approach in

331 which substages and stages were defined according to Milanković insolation cycles.

332 However, either approach would eliminate any continuity with the previous literature,

333 because MIS 5 would become MIS 3, as discussed in Section 2.2, and MIS 5e would become 
334 MIS 3e if not MIS 3c. With an algorithmic or theoretical approach, the earlier substages of

335 MIS 18 would likely become substages of MIS 19, which would, with the elimination of

336 present MIS 3 and 4, become MIS 17. Similarly, an algorithmic or theoretical approach

337 would likely designate MIS 24 as a substage of one stage consisting of present Stages 23 to

338 25, all of which would, with the elimination of present MIS 3 and 4, become MIS 21 - and

339 the result would be great confusion between previous and future publications.

340 2c) Substages that are consistent with designations by previous workers (Table 2) to the

341 maximum extent possible.

342 3) Assignment of all intervals of time to stages and substages, in accord with Fig. 1 of Emiliani

343 (1955) and in contrast to the schemes of Pisias et al. (1984) and Prell et al. (1986) for events.

344 4) Explicit divisions between, and thus definition of, each substage, as shown for the stages of

345 Fig. 1 of Emiliani (1955) and the substages of Fig. 1 of Shackleton (1969) but rarely shown in

346 subsequent publications.

347 5) No substages that are left unidentified (e.g., no "b"s left unused or merely implicit between

348 "a"s and "c"s), in contrast to many designations of substages prior to MIS 5e.

349 Applying these goals has led us to the scheme of substages shown in Fig. 3. No

350 substages are designated for MIS 1 (the Holocene), MIS 2, and MIS 4 for three reasons: they are

351 all brief stages, they are stages for which substages have never been designated in marine records,

352 and they are in the time interval in which numbered Greenland Stadials and Greenland

353 Interstadials (Dansgaard et al., 1993; Eiriksson et al., 2000) are now widely applied in

354 recognizing substage-scale periods (e.g., Schulz et al., 1997). For MIS 3, which is almost as long

355 as MIS 1, 2 and 4 combined, the three substages are those recognized by Carey et al. (2005) in

356 East Pacific Core V19-30 and by Wright et al. (2009) in the North Atlantic, and they are similar

357 to those of Wu et al. (2004) in data from Tibetan ice. They are evident in LR04 and further

358 supported by the Tenaghi Philippon record of Tzedakis et al. (2006). The five substages of MIS 5

359 shown are those of Shackleton (1969), which he defined relative to a generalized oxygen isotope 
360 record. The five substages of MIS 6, which were first designated by Sun and An (2005), are

361 easily recognized in the LR04 record, and are further supported by the Chinese loess record of

362 Sun et al. (2006) (Fig. 3). The five substages of MIS 7 and 9, which are easily recognized in

363 LR04, are those designated by Tzedakis et al. (1997). The three substages of MIS 8 are clearly

364 recognized in the LR04 record and further supported by the Lake Baikal and Tenaghi Philippon

365 records of Prokopenko et al. (2006) and Tzedakis et al. (2006), respectively. The three substages

366 of MIS 10 are easily recognized in LR04, are strongly supported by Antarctic ice and Tenaghi

367 Philippon records in Fig. 3, and are in accord with the MIS 10a, 10b, and 10c discussed but not

368 illustrated by Lundberg and McFarlane (2007). The substages of MIS 11 can be recognized in

369 LR04 and are strongly supported by the Antarctic and Lake Baikal records. The three substages

370 of MIS 12 are most readily recognized in the marine record of Hodell et al. (2008). The three

371 stages of MIS 13 are readily evident in the marine records of Fig. 3 and additionally supported by

372 the Antarctic ice, Tenaghi Philippon pollen, and Chinese loess records. The three substages of

373 MIS 14 are readily evident in the marine record of Hodell et al. (2008). The five substages of

374 MIS 15 first designated by Khursevich et al. (2001) can be recognized in the LR04 record and are

375 also evident in the marine record of Hodell et al. (2008) and the Antarctic ice record of Jouzel et

376 al. (2007). The three substages of MIS 16 first designated by Sun and An (2005) are recognizable

377 in the marine records of Hodell et al. (2008) and Fig. 2 of Naafs et al. (2011), and they are further

378 supported by the Antarctic ice record of Jouzel et al. (2007) and the Chinese loess record of Sun

379 et al. (2006) (Fig. 3). The five stages of MIS 17 are evident in LR04 and supported by the Lake

380 Baikal record of Prokopenko et al. (2006). The five substages of MIS 18 are evident in LR04 and

381 the marine record of Hodell et al. (2008), and they are supported by the Lake Baikal record of

382 Prokopenko et al. (2006). The three substages of MIS 19 were first designated by Tzedakis et al.

383 (2012 a, b) and can be recognized in LR04. The four substages of MIS 20 are evident in the

384 marine record of Hodell et al. (2008). The seven substages of MIS 21 are evident in the marine

385 records of Hodell et al. (2008) and Fig. 2 of Naafs et al. (2011), and less clearly but arguably in 
386 LR04. They also parallel the seven numbered substages recognized by Ferreti et al. (2010). MIS

$38722,24,26$, and 27 are sufficiently brief and invariant that there is little justification for

388 designating substages within them. On the other hand, the three substages of MIS 23 and five

389 substages of MIS 25 can be recognized in LR04, and the latter are supported by the Lake Baikal

390 record of Prokopenko et al. (2006).

391 We have extended this scheme back 1.0 million years, and thus to MIS 27, because

392 marine isotope stages before that time are both sufficiently short and their oxygen isotope data are

393 sufficiently uniform internally that substages seem unnecessary at the present state of knowledge.

394 Furthermore, U-Th dating has made detailed chronologies possible over the last 550,000 years

395 and thus has necessitated substages back to MIS 14, but the use of substages before MIS 14 will

396 presumably be less extensive. The compilation of usage in the literature shown in Table 1

397 suggests little applicability of substages before MIS 20 at about $800 \mathrm{ka}$, further suggesting little

398 need to define substages before 1.0 million years - although it is implicit that the scheme

399 proposed herein could in the future be extended further backwards if found desirable.

400 As isotopic records are further refined in the future, workers may also find it useful to

401 define shorter-term oscillations in the marine record and thus to subdivide the marine isotope

402 substages. With regard to marine isotope records, one step in that direction was taken by Bauch

403 and Erlenkeuser (2008), who within MIS 5e recognized one interval, MIS 5e-ss, where "ss"

404 represented "sensu stricto". That interval may have been similar to the MIS 5e "plateau" noted

405 by Shackleton et al. (2003), which falls within the limits of MIS 5e. However, neither

406 designation was part of a larger system of contiguous intervals within MIS substages, and the

407 current state of marine isotopic and other records may make any attempt at such refinement

408 premature now. Outside the realm of marine isotope stages, but in parallel with their usage,

409 Dansgaard et al. (1993) and Greenland Ice Core Project (GRIP) Members (1993) recognized

410 subdivisions of MIS 5e that they designated "MIS 5e1 to 5e5" in the GRIP $\delta^{18} \mathrm{O}$ record. For the

411 marine isotope record, we recommend the same scheme for labelling the subdivisions of 
412 substages.

\section{5. The diversification of names and applications of stages, and its implications}

\section{5.1. Diversification}

416 In the mid-1980s, the "stages" of Arrhenius (1952), "core stages" of Emiliani (1955,

417 1966), and then "isotope stages" of Shackleton (1969) and Shackleton and Opdyke (1973)

418 progressed to " ${ }^{18} \mathrm{O}$ stages" and " $\delta{ }^{18} \mathrm{O}$ stages" (Kukla, 1977) and "oxygen isotope stages" (e.g.,

419 Prell et al., 1986) and "marine isotope stages" (e.g. Porter, 1987), and most thoroughly to "marine

420 oxygen isotope stages" (Scott et al., 1983). This was a progression toward greater specificity, as

421 is shown by Fig. 4. However, time-series of isotopic data from marine sediments are so

422 dominated by oxygen isotope data that "marine isotope stage" and "marine oxygen isotope stage"

423 are nearly synonymous (Fig. 4), leading to the frequent and familiar use of "Marine Isotope

424 Stage" and thus "MIS".

425 The material to which the terminology of marine isotope stages has been applied has also 426 evolved, in that stages that were defined in oxygen isotope data from marine sediments have been 427 used to label intervals in time-series of very different parameters from very different materials in 428 very different settings. Examples include "oxygen isotope stages" applied to time-series of ${ }^{10} \mathrm{Be}$ 429 concentration data in Fig. 4 of Eisenhauer et al. (1994), "oxygen isotope stages" applied to time430 series of pollen data in Fig. 5 of Seidenkrantz et al. (1996), "isotope stages" applied to time-series 431 of data about ice-rafted debris in Fig. 3 of Forsström (2001), and "marine isotope stages" applied 432 to time-series of $\delta^{18} \mathrm{O}$ data from $\mathrm{CaCO}_{3}$ of stalagmites in Fig. 1 of Wang et al. (2008) and to time433 series of deuterium concentrations in the EPICA Dome C ice core in Antarctica in Fig. 4 of Hur 434 et al. (2013). Even more strikingly, "MIS 5e1 to 5e5" were defined relative to an ice-core record, 435 rather than a marine record (Greenland Ice Core Project (GRIP) Members, 1993, their Fig. 2). 
The blurring of distinctions in materials and settings discussed above can mask

439 differences in timing that can result from different time lags of different proxies, from different

440 latitudinal settings, and from locations in different ocean basins (Fig. 5). For example, a

441 transition defining the end of a substage or stage may progress in time from a low-latitude marine

442 sedimentary record to mid-latitude stalagmite records (each with different time lags imposed by

443 different rates of groundwater movement) to a high-latitude pollen record or an alpine ice-core

444 record. Even within one type of data, benthic foraminiferal $\delta^{18} \mathrm{O}$ records, Skinner and

445 Shackleton (2005) found a 4-kyr Atlantic lead over the Pacific for the last deglaciation, caused by

446 a local or basin-restricted component of this signal. Hodell et al. (2013, their paragraph 50) have

447 pointed out similar lags in marine $\delta^{18} \mathrm{O}$ records. It follows that numbered Quaternary stages

448 (packages of sediment characterized by data recovered from them) are less ages (intervals of

449 time) than facies (packages of sediment that may be deposited at slightly different times in

450 different places in response to moving sets of depositional conditions and/or locally anomalous

451 conditions) (Table 1). Indeed, the International Stratigraphic Guide (Salvador, 1994, p. 10) would

452 consider these isotopic stages as zones akin to the range zones and assemblage zones of

453 biostratigraphy or to the polarity zones of magnetostratigraphy. If we were to start isotope

454 chronostratigraphy anew, as Wright et al. (2009) aspired when they proposed the use of "marine

455 isotope chron" and thus "MIC" as a time term, we would call these units "marine isotope zones"

456 labelled "MIZ" - but the desirability of nomenclatural stability dictates continued use of the

457 customary, if technically incorrect, "marine isotope stage".

458 Because of the possibility of time mismatches caused by differences in kinds of data and

459 by contrasting hydrographic settings, some authors may have been wise when, for example, they

460 chose to call the MIS-like numbered intervals "climatic stages" when applied to time-series of

461 paleomagnetic data (Rafalli et al., 1996) and to time-series of $\delta D$ and dust data (Delmonte et al.,

462 2004) (Fig. 4). Even Cesare Emiliani himself referred to the isotopically-defined intervals as 
463 "climatic stages" (Gartner and Emiliani, 1976). His usage is a reminder that all numbered

464 Quaternary stages, whether identified in marine isotopic records, spelean isotopic records, pollen

465 records, etc., have potentially diachronous transitions controlled by individual responses to

466 changing climate, and they are therefore "climatic stages" in the climatostratigraphic paradigm.

467 Thus, to use the example in Fig. 5, our proposed scheme of lettered substages (Fig. 3) attempts to

468 eliminate confusion in the literature between Substage $n$ a and Substage $n c$, but no such scheme

469 can eliminate the possibility that the transition from Substage $n \mathrm{~b}$ to Substage $n$ a occurred at

470 slightly different times in different places and/or in different records.

\section{6. Consideration of potential problems in application to other records}

473 The widespread designation of marine isotope substages discussed in Sections 2 and 3

474 suggests that the concept of substages is applicable to many records, both marine and non-marine.

475 One might question how applicable this concept can be to discontinuous records from which

476 some substages are missing, but examination of the Tianmen Cave (Cai et al., 2010) and Kesang

477 Cave (Cheng et al., 2012) spelean records demonstrates that substages can be applied in

478 radiometrically dated records with missing intervals. The Tianmen Cave stalagmites from the

479 Tibetan Plateau were deposited over only about 30,000 of the last 120,000 years, but U-series

480 dates combined with changes in $\delta^{18} \mathrm{O}$ allowed clear assignment of stalagmite intervals to Marine

481 Isotope Substages 5a, 5c, and 5e (Cai et al., 2010). Similarly, the Kesang Cave stalagmites from

482 northwestern China were deposited over only about 80,000 of the last 130,000 years, but U-series

483 dates and variation in $\delta^{18} \mathrm{O}$ allowed recognition of Marine Isotope Stages 1 and 3 and of

484 Substages 5a, 5c, and 5e (Cheng et al., 2012). In this respect, it is fortunate that speleothems, the

485 paleoclimate records whose sensitivity to climate change makes them most prone to hiatuses

486 (Railsback et al., 2013), are the records most readily dated by radiometric methods.

487 One might also question whether antiphasing might cause confusion in recognition of

488 substages, in that a cold substage in one hemisphere might be a warm substage in the other. 
489 However, several considerations combine to suggest that antiphasing should not be a major

490 concern. First, our use of a benthic oxygen isotope record to define substages means that the

491 substages are largely a function of changes in global ice volume (Shackleton, 2000; Elderfield et

492 al., 2012), which is inherently an interhemispherical signal changing at time scales considerably

493 greater than the mixing time of the oceans (Broecker and Peng, 1982). Secondly, modeling of

494 changing ice volume suggests that, although antiphasing may have been an issue prior to about 1

495 million years ago, it has not been significant over the last million years (Raymo et al., 2006),

496 although it is acknowledged that the harmonics of precession are significant features of some

497 North Atlantic benthic oxygen isotope records (Ferretti et al, 2010), raising issues of potential

498 antiphasing. Thirdly, the magnitude in offsets in Dansgaard-Oeschger events between northern

499 and southern polar regions of 200 to 400 years (Hinnov et al., 2002) and in the bipolar see-saw

500 with its offset of 1500 to 3000 years (Blunier and Brook, 2001) is sufficient to cause the sort of

501 lags discussed in Section 5 but not sufficient to cause antiphasing of substages, given that our

502 scheme of 94 substages across 1.0 million years gives an average duration for substages of more

503 than 10 thousand years.

504 The arguments in the preceding paragraph apply mainly to benthic marine records and to

505 records from high-latitude accumulations of ice. On the other hand, mid-latitude continental

506 records and planktonic marine records may be more subject to antiphasing that would complicate

507 application of substages. In the middle latitudes, fluctuations of continental climate are commonly

508 linked to monsoonal variations, and increases in northern or southern hemisphere insolation can

509 shift the Inter-Tropical Convergence Zone to the north or south and lead to more extensive

510 monsoonal rainfall in the northern or southern hemispheres, respectively (e.g., Janicot, 2009).

511 For example, Partridge et al. (1997) found an antiphase relationship in the North African and

512 South African monsoons at orbital (precession) time scales. These longer-term antiphase

513 relationships among various individual continental records may further demonstrate the

514 importance of defining global substages relative to stacked marine benthic records. 


\section{7. Summary}

517 Careful examination of the literature reveals that later Cenozoic time has been identified

518 by two alphanumeric systems arising from the division of deep-sea sediment sequences, one

519 identifying contiguous intervals by the use of numbered stages divided into lettered substages

520 (Fig. 1B), and the other identifying non-contiguous events by the use of decimal-style numbers

521 (Fig. 1C, 1D, and 1E). However, because the lettering of substages other than those of MIS 5 has

522 never been formally defined, many conflicting designations and systems have been used for

523 substages over the last twenty years (e.g., Fig. 2). We therefore propose one complete scheme

524 (Fig. 3), with no internal contradictions and as compatible as possible with previous usage, for

525 use henceforth in identifying substages in time-series of isotopic, as well as other, data (Fig. 4).

526 This scheme, defined relative to the LR04 stack of marine benthic oxygen isotope records,

527 extends designation of substages back to MIS 28, and thus back in time 1.0 million years.

\section{Acknowledgements}

530 The manuscript was improved by the comments of Dr. Alan G. Smith of the Department

531 of Earth Sciences of the University of Cambridge and Dr. Kim Cohen of the Faculty of

532 Geosciences of Utrecht University. It benefited also from the advice of Dr. Jeroen Groeneveld of

533 the Department of Geosciences of the University of Bremen, Dr. Youbin Sun of the Institute of

534 Earth Environment of the Chinese Academy of Sciences in Xian, Dr. Martin Melles of the

535 Faculty of Mathematics and Natural Sciences of the University of Cologne, and Dr. Andreas

536 Koutsodendris of the Institute of Earth Sciences of Ruprecht-Karls-Universität in Heidelberg.

537 Professor Polychronis Tzedakis of the Department of Geography of University College, London,

538 kindly provided the otherwise unavailable pollen data for Tenaghi Philippon. The manuscript

539 was greatly improved by a review for $Q S R$ by Professor Lorraine Lisiecki of the University of

540 California at Santa Barbara. 


\section{$541 \quad$ References}

542 Arrhenius, G., 1952. Sediment cores from the East Pacific. Reports of the Swedish Deep-Sea

543 Expedition 1947-1948 5, Fasc. 1, 227 p.

545 Ashton, N., Lewis, S.G., Parfitt, S.A., Penkman, K.E.H., Coope, G.R., 2008. New evidence for

546 complex climate change in MIS 11 from Hoxne, Suffolk, UK: Quaternary Science Reviews 27,

$547 \quad 652-668$.

549 Ashton, N.M., 2010. Challenges to the Occupation of North-West Europe during the late Middle

550 Pleistocene. Ph.D. Dissertation, University of Leiden.

552 Bassinot, F.C., Labeyrie, L.D., Vincent, E., Quidelleur, X., Shackleton, N.J., Lancelot, Y., 1994.

553 The astronomical theory of climate and the age of the Brunhes-Matuyama Magnetic Reversal:

554 Earth and Planetary Science Letters 126, 91-108.

555

556 Bazin, L., Landais, A., Lemieux-Dudon, B., Kele, H.T.M., Veres, D., Parrenin, F., Martinerie, P.,

557 Ritz, C., Capron, E., Lipenkov, V., Loutre, M.F., Raynaud, D., Vinther, B., Svensson, A.,

558 Rasmussen, S.O., Severi, M., Blunier, T., Leuenberger, M., Fischer, H., Masson-Delmotte, V.,

559 Chappellaz, J., Wolff, E., 2013. An optimized multi-proxy, multi-site Antarctic ice and gas orbital

560 chronology (AICC2012): 120-800 ka. Climate of the Past 9,1715-1731.

561

562 Blunier, T., Brook, E.J., 2001. Timing of millennial-scale climate change in Antarctica and

563 Greenland during the last glacial period. Science 291, 109-112.

564

565 Bradley, R.S., 1999. Paleoclimatology: Reconstructing Climates of the Quaternary, second ed.

566 San Diego, Academic Press, 613 pp. 
568 Bradley, R.S., 2015. Paleoclimatology: Reconstructing Climates of the Quaternary, third ed.

569 Amsterdam, Elsevier, 675 pp.

570

571 Broecker, W.S., Peng, T.-H., 1982. Tracers in the Sea. Palisades, N.Y. : Lamont-Doherty

572 Geological Observatory, 690 p.

573

574 Broecker, W.S., van Donk, J., 1970. Insolation changes, ice volumes, and the $\mathrm{O}^{18}$ record in deep575 sea cores. Reviews of Geophysics and Space Physics 8, 169-198.

577 Bühring, C., Sarnthein, M., Erlenkeuser, H., 2004. Toward a high-resolution stable isotope 578 stratigraphy of the last 1.1 m.y.: Site 1144, South China Sea, in Prell, W.L., Wang, P., Blum, P.,

579 Rea, D.K., and Clemens, S.C. (Eds.), Proceedings of the Ocean Drilling Program, Scientific

$580 \quad$ Results 184, 1-29.

581

582 Bussell, M.R., Pillans, B., 1992. Vegetational and climatic history during Oxygen Isotope Stage

583 9, Wanganui District, New Zealand, and correlation of the Fordell Ash: Journal of the Royal

584 Society of New Zealand 22, 41-60.

586 Bussell, M.R., Pillans, B., 1997. Vegetational and climatic history during oxygen isotope stage 7

587 and early stage 6, Taranaki, New Zealand: Journal of the Royal Society of New Zealand 27, 419588438. 
590 Cai, Y. J., et al. (2010), Oxygen isotope records of precipitation from the south-central Tibetan

591 Plateau during the last interglaciation: Clues from speleothems, Geology, 38, 243-246,

592 doi:10.1130/G30306.1.

593

594 Carey, J.S., Sheridan, R.E., Ashley, G.M., Uptegrove, J., 2005. Glacially-influenced late

595 Pleistocene stratigraphy of a passive margin: New Jersey's record of the North American ice 596 sheet. Marine Geology 218, 155-173.

598 Chamberlin, T.C., 1895. The classification of American glacial deposits. Journal of Geology 3, $599270-277$.

600

601 Cheng, H., Edwards, R. L., Broecker, W. S., Denton, G. H., Kong, X., Wang, Y., Zhang, R.,

602 Wang, X., 2009. Ice age terminations. Science 326, 248-252.

603

604 Cheng, H., Zhang, P.Z.. Spötl, C., Edwards, R.L., Cai, Y.J., Zhang, D.Z., Sang, D.Z., Tan, M., 605 An, Z.S., 2012. The climatic cyclicity in semiarid-arid central Asia over the past 500,000 years.

606 Geophysical Research Letters, 39, L01705.

607

608 Cita, M.B., Gibbard, P.L., Head, M.J., ICS Subcommission on Quaternary Stratigraphy, 2012.

609 Formal ratification of the GSSP for the base of the Calabrian Stage (second stage of the

610 Pleistocene Series, Quaternary System): Episodes 35, 388-397.

612 Cohen, K. M., Finney, S.C., Gibbard, P., Fan, J.-X., 2013. The ICS International

613 Chronostratigraphic Chart. Episodes 36, 199-204.

614

615 Cohen, K. M., Gibbard, P., 2011, Global chronostratigraphical correlation table for the last 2.7 
616 million years. Subcommission on Quaternary Stratigraphy (International Commission on

617 Stratigraphy), Cambridge, England.

618

619 Compton, J.S., 2011. Pleistocene sea-level fluctuations and human evolution on the southern

620 coastal plain of South Africa. Quaternary Science Reviews 30, 506-527.

622 Dansgaard, W., Johnsen, S.J., Clausen, H.B., Dahl-Jensen, D., Gundestrup, N.S., Hammer, C.U.,

623 Hvidberg, C.S., Steffensen, J.P., Sveinbjörnsdottir, A.E., Jouzel, J., Bond, G., 1993. Evidence for

624 general instability of past climate from a 250-kyr ice-core record. Nature 364, 218-220.

625

626 de Abreu, C., Abrantes, F.F., Shackleton, N.J., Tzedakis, P.C., McManus, J. F., Oppo, D.W.,

627 Hall, M.A., 2005. Ocean climate variability in the eastern North Atlantic during interglacial

628 marine isotope stage 11: A partial analogue to the Holocene? Paleoceanography 20, PA3009.

630 Delmonte, B., Basile-Doelsch, I., Petit, J.R., Maggi, V., Revel-Rolland, M., Michard, A., Jagoutz,

631 E. Grousset, F., 2004. Comparing the Epica and Vostok dust records during the last 220,000

632 years: stratigraphical correlation and provenance in glacial periods. Earth-Science Reviews 66, $633 \quad 63-87$.

634

635 Desprat, S., Goni, M.F.S., Naughton, F., Turon, J.L., Duprat, J., Malaize, B., Cortijo, E.,

636 Peypouquet, J.P., 2007. Climate Variability of the Last Five Isotopic Interglacials: Direct Land-

637 Sea-Ice Correlation from the Multiproxy Analysis of North-Western Iberian Margin Deep-Sea

638 Cores. In Sirocko, F. Claussen, M., Sánchez Goñi, M.F., Litt, T. (eds.), Climate of Past

639 Interglacials. Developments in Quaternary Science 7, 375-386.

640 
641 Eiríksson, J., Knudsen, K.L., Haflidason, H., Henriksen, P., 2000. Late-glacial and Holocene

642 palaeoceanography of the North Icelandic shelf. Journal of Quaternary Science 15, 23-42.

644 Eisenhauer, A., Spielhagen, R. F., Frank, M., Hentzschel, G., Mangini, A., Kubik, P.W.,

645 Dittrichhannen, B., Billen, T., 1994. ${ }^{10}$ Be records of sediment cores from high northern latitudes:

646 Implications for environmental and climatic changes. Earth and Planetary Science Letters 124,

$647 \quad 171-184$.

648

649 Elderfield, H., Ferretti, P., Greaves, M., Crowhurst, S., McCave, I.N., Hodell, D., Piotrowski,

650 A.M., 2012. Evolution of ocean temperature and ice volume through the mid-Pleistocene climate 651 transition. Science 337, 704-709.

652

653 Emiliani, C., 1955. Pleistocene temperatures. Journal of Geology 63, 538-578.

654

655 Emiliani, C., 1961. Cenozoic climate changes as indicated by the stratigraphy and chronology of 656 deep-sea cores of Globigerina-ooze facies. Annals of the New York Academy of Sciences 95, $657 \quad 521-536$.

658

659 Emiliani, C., 1966. Paleotemperature analysis of Caribbean cores P6304-8 and P6304-9 and a

660 generalized temperature curve for the past 425,000 years. Journal of Geology 74, 109-124.

661

662 Ferretti, P., Crowhurst, S.J., Hall, M.A., Cacho, I., 2010. North Atlantic millennial-scale climate

663 variability 910 to $790 \mathrm{ka}$ and the role of the equatorial insolation forcing. Earth and Planetary

664 Science Letters 293, 28-41.

665 
666 Flint, R.F., 1947. Glacial Geology and the Pleistocene Epoch. J. Wiley and Sons (Eds.), New

667 York, $589 \mathrm{p}$.

668

669 Forsström, L., 2001. Duration of interglacials: a controversial question. Quaternary Science

670 Reviews 20, 1577-1586.

671

672 Gartner, S., Emiliani, C., 1976. Nannofossil biostratigraphy and climatic stages of Pleistocene

673 Brunhes Epoch: American Association of Petroleum Geologists Bulletin 60, 1562-1564.

674

675 Geikie, J., 1894. The Great Ice Age and its relation to the Antiquity of Man, third ed.

676 Stanford, London.

677

678 Gibbard. P.L., 2014. Terrestrial stratigraphical division in the Quaternary and its

679 correlation. Journal of Quaternary Science, in press.

680

681 Gibbard, P., Cohen, K.M., 2008. Global chronostratigraphical correlation table for the last 2.7

682 million years. Episodes 31, 243-247.

683

684 Greenland Ice Core Project (GRIP) Members, 1993. Climate instability during the last interglacial 685 period recorded in the GRIP ice core. Nature 364, 203-207.

687 Harland, W.B., 1992. Stratigraphic regulation and guidance - a critique of current tendencies in 688 stratigraphic codes and guides. Geological Society of America Bulletin 104, 1231-1235.

690 Hernández-Almeida, I., Sierro, F.J., Flores, J.A., Cacho, I., Filippelli, G.M., 2013.

691 Palaeoceanographic changes in the North Atlantic during the Mid-Pleistocene Transition (MIS 
692 31-19) as inferred from planktonic foraminiferal and calcium carbonate records. Boreas 42, 140693159.

695 Hinnov, L.A., Schulz, M., Yiuo, P., 2002. Interhemispheric space-time attributes of the

696 Dansgaard-Oeschger oscillations between 100 and 0 ka. Quaternary Science Reviews 21, 12136971228.

699 Hodell, D.A., Channell, J.E.T., Curtis, J.H, Romero, O.E., Röhl, U., 2008. Onset of 'Hudson

700 Strait' Heinrich Events in the eastern North Atlantic at the end of the middle Pleistocene

701 transition ( 640 ka)? Paleoceanography, 23, PA4218, doi:10.1029/2008PA001591.

703 Hodell, D., Crowhurst, S., Skinner, L., Tzedakis, P.C., Margari, V., Channell, J.E.T., Kamenov,

704 G., Maclachlan, S., and Rothwell, G., 2013. Response of Iberian Margin sediments to orbital and

705 suborbital forcing over the past $420 \mathrm{ka}$. Paleoceanography 28, 185-199.

706

707 Hur, S.D., Soyol-Erdene, T.O., Hwang, H.J., Han, C., Gabrielli, P., Barbante, C., Boutron, C.F., 708 Hong, S., 2013. Climate-related variations in atmospheric Sb and Tl in the EPICA Dome C ice 709 (East Antarctica) during the past 800,000 years. Global Biogeochemical Cycles 27, 930-940.

711 Imbrie, J., Hays, J.D., Martinson, D.G., McIntyre, A., Mix, A.C., Morley, J.J., Pisias, N.G., Prell,

712 W.L., Shackleton, N.J., 1984. The orbital theory of Pleistocene climate: support from a revised

713 chronology of the marine $\delta^{18}$ O record. In: Berger, A., Imbrie, J., Hays, J., Kukla, G., Saltzman, B.

714 (Eds.), Milankovitch and Climate: Understanding the Response to Astronomical Forcing. D.

715 Reidel Publishing Co., Dordrecht, pp. 269-305.

716

717 Jahns, S., Hüls, M., Sarnthein, M., 1998. Vegetation and climate history of west equatorial Africa 
718 based on a marine pollen record off Liberia (site GIK 16776) covering the last 400,000 years.

719 Review of Palaeobotany and Palynology 102 (1998) 277-288.

721 Janicot, S., 2009. A comparison of Indian and African monsoon variability at different time 722 scales. Comptes Rendus Geoscience 341, 575-590.

724 Jouzel, J., Masson-Delmotte, V., Cattani, O., Dreyfus, G., Falourd, S., Hoffmann, G., Minster, B., 725 Nouet, J., Barnola, J.M., Chappellaz, J., Fischer, H., Gallet, J.C., Johnsen, S., Leuenberger, M., 726 Loulergue, L., Luethi, D., Oerter, H., Parrenin, F., Raisbeck, G., Raynaud, D., Schilt, A., 727 Schwander, J., Selmo, E., Souchez, R., Spahni, R., Stauffer, B., Steffensen, J.P., Stenni, B., 728 Stocker, T.F., Tison, J.L., Werner, M., Wolff, E.W., 2007. Orbital and millennial Antarctic 729 climate variability over the past 800,000 years. Science $317,793-796$.

731 Kawamura, K., Parrenin, F., Lisiecki, L., Uemura, R., Vimeux, F., Severinghaus, J.P., Hutterli,

732 M. A., Nakazawa, T., Aoki, S., Jouzel, J., Raymo, M. E., Matsumoto, K., Nakata, H., Motoyama, 733 H., Fujita, S., Goto-Azuma, K., Fujii, Y., Watanabe, O., 2007. Northern Hemisphere forcing of 734 climatic cycles in Antarctica over the past 360,000 years. Nature 448, 912-916.

736 Khursevich, G.K., Karabanov, E.B., Prokopenko, A.A., Williams, D.F., Kuzmin, M.I., Fedenya, 737 S.A., Gvozdkov, A.A., 2001. Insolation regime in Siberia as a major factor controlling diatom 738 production in Lake Baikal during the past 800,000 years. Quaternary International 80-81, 47-58.

740 Kitaba, I., Harada, M., Hyodo, M., Katoh, S., Sato, H., Matsushita, M., 2011. MIS 21 and the 741 Mid-Pleistocene climate transition: Climate and sea-level variation from a sediment core in Osaka 742 Bay, Japan. Palaeogeography Palaeoclimatology Palaeoecology 299, 227-239. 
744 Kukla, G.J., 1977. Pleistocene land-sea correlations I: Europe. Earth-Science Reviews 13, 307-

745374.

746

747 Leighton, M.M., 1933. The naming of the subdivisions of the Wisconsin glacial age. Science 77, $748 \quad 168$.

750 Lisiecki, L.E., Raymo, M.E., 2005. A Pliocene-Pleistocene stack of 57 globally distributed

751 benthic $\delta^{18} \mathrm{O}$ records. Paleoceanography 20, PA1003.

753 Lundberg, J., McFarlane, D.A., 2007. Pleistocene depositional history in a periglacial terrane: A

754500 k.y. record from Kents Cavern, Devon, United Kingdom. Geosphere 3, 199-219.

755

756 Maier, P.L., 1989. The date of the nativity and chronology of Jesus. In Vardaman, J, Yamauchi,

757 E.M., eds. Chronos, Kairos, Christos: nativity and chronological studies presented to Jack

758 Finegan. Winona Lake, Indiana, Eisenbrauns, 113-129.

759

760 Mangerud, J., Andersen, S. T., Berglund, B. E. \& Donner, J. J., 1974. Quaternary stratigraphy of

761 Norden, a proposal for terminology and classification. Boreas 3, 109-128.

762

763 Martinson, D.G., Pisias, N.G., Hays, J.D., Imbrie, J., Moore, T.C., Shackleton, N.J., 1987. Age

764 dating and the orbital theory of the ice ages: development of a high-resolution 0 to 300,000-year

765 chronostratigraphy. Quaternary Research 27, 1-29.

766

767 Melles, M., Brigham-Grette, J., Glushkova, O.Y., Minyuk, P.S., Nowaczyk, N.R., Hubberten, 768 H.W., 2007. Sedimentary geochemistry of core PG1351 from Lake El'gygytgyn - a sensitive 
769 record of climate variability in the East Siberian Arctic during the past three glacial-interglacial

770 cycles. Journal of Paleolimnology 37, 89-104.

771

772 Muhs, D.R., Meco, J., Simmons, K.R., 2014. Uranium-series ages of corals, sea level history, and

773 palaeozoogeography, Canary Islands, Spain: An exploratory study for two Quaternary interglacial

774 periods. Palaeogeography Palaeoclimatology Palaeoecology 394, 99-118.

775

776 Ninkovich, D., Shackleton, N.J., 1975. Distribution, stratigraphic position and age of Ash Layer-

777 L, in Panama Basin region. Earth and Planetary Science Letters 27, 20-34.

779 Partridge, T.C., Demenocal, P.B., Lorentz, S.A., Paiker, M.J., Vogel, J.C., 1997. Orbital forcing

780 of climate over South Africa: a 200,000-year rainfall record from the Pretoria Saltpan. Quaternary

781 Science Reviews 16, 1125-1133.

782

783 Pisias, N.G., Martinson, D.G., Moore, T.C., Shackleton, N.J., Prell, W., Hays, J., Boden, G.,

784 1984. High-resolution stratigraphic correlation of benthic oxygen isotopic records spanning the

785 last 300,000 years. Marine Geology 56, 119-136.

786

787 Plagnes, V., Causse, C., Dominique, G., Paterne, M., Blamart, D., 2002. A discontinuous climatic 788 record from 187 to 74 ka from a speleothem of the Clamouse Cave (south of France). Earth and 789 Planetary Science Letters 201, 87-103.

791 Poli, M.S., Meyers, P.A., Thunell, R.C., Capodivacca, M., 2012. Glacial-interglacial variations in 792 sediment organic carbon accumulation and benthic foraminiferal assemblages on the Bermuda

793 Rise (ODP Site 1063) during MIS 13 to 10. Paleoceanography, 27, PA3216,

794 doi:10.1029/2012PA002314. 
796 Porter, S.C., 1987. Pleistocene subglacial eruptions on Mauna Kea, in Decker, R.W., Wright,

797 T.L., Stauffer, P.H. (Eds.), Volcanism in Hawaii. U. S. Geological Survey Professional Paper

$798 \quad 1350,587-598$.

800 Prell, W.L., Imbrie, J., Martinson, D.G., Morley, J.J., Pisias, N.G., Shackleton, N.J., Streeter,

801 H.F., 1986. Graphic correlation of oxygen isotope stratigraphy. Application to the Late

802 Quaternary. Paleoceanography 1, 137-162.

803

804 Prokopenko, A.A., Karabanov, E.B., Williams, D.F., Kuzmin, M.I., Shackleton, N.J., Crowhurst, 805 S.J., Peck, J.A., Gvozdkov, A.N., King, J.W., 2001. Biogenic silica record of the Lake Baikal

806 response to climatic forcing during the Brunhes. Quaternary Research 55, 123-132.

807

808 Prokopenko, A.A., Hinnov, L.A., , Williams, D.F., Kuzmin, M.I., 2006. Orbital forcing of

809 continental climate during the Pleistocene: a complete astronomically tuned climatic record from

810 Lake Baikal, SE Siberia. Quaternary Science Reviews 25, 3431-3457.

811

812 Raffalli, G., Kissel, C., van Weering, T., van der Gaast, S., 1996. First analysis of mineral

813 magnetic changes related to climatic Stage 3 at the Faeroe Islands margin. Eos, Transactions,

814 American Geophysical Union 77, F22.

815

816 Railsback, L.B., Akers, P.D., Wang, L., Holdridge, G.A., Voarintsoa, N., 2013. Layer-bounding

817 surfaces in stalagmites as keys to better paleoclimatological histories and chronologies.

818 International Journal of Speleology 42, 167-180. 
820 Railsback, L.B., Xiao, H., Liang, F., Akers, P.D., Brook, G.A., Dennis, W.M., Lanier, T.E.,

821 Cheng, H., Edwards, R.L., 2014. A stalagmite record of abrupt climate change and possible

822 Westerlies-derived atmospheric precipitation during the Penultimate Glacial Maximum in

823 northern China. Palaeogeography, Palaeoclimatology, Palaeoecology 393, 30-44.

824

825 Raymo, M.E., Lisiecki, L.E., Nisancioglu, K.H., 2006. Plio-Pleistocene ice volume, Antarctic

826 climate, and the global $\delta^{18} \mathrm{O}$ record. Science $313,492-495$.

827

828 Raymo, M.E., Ruddiman, W.F., Backman, J., Clement, B.M., Martinson, D.G., 1989. Late

829 Pliocene variation in Northern Hemisphere ice sheets and North Atlantic Deep Water circulation.

830 Paleoceanography 4, 413-446.

831

832 Robinson, L.F., Henderson, G.M., Slowey, N.C., 2002. U-Th dating of marine isotope stage 7 in

833 Bahamas slope sediments. Earth and Planetary Science Letters 196, 175-187.

835 Ruddiman, W.F., Raymo, M.E., Martinson, D.G., Clement, B.M., Backman, J., 1989. Pleistocene

836 evolution: Northern Hemisphere ice sheets and North Atlantic Ocean. Paleoceanography 4, 353-

837412.

838

839 Ruddiman, W.F., 2006. Orbital changes and climate. Quaternary Science Reviews 25, 3092-

$840 \quad 3112$.

841

842 Salvador, A., 1994. International stratigraphic guide (2nd. edn.). Boulder, Colorado, Geological

843 Society of America, 214 pp. 
845 Schreve, D.C., 2001. Mammalian evidence from Middle Pleistocene fluvial sequences for

846 complex environmental change at the oxygen isotope substage level. Quaternary International 79,

$847 \quad 65-74$.

848

849 Schulz, H., von Rad, U., Erlenkeuser, H., 1998. Correlation between Arabian Sea and Greenland

850 climate oscillations of the past 110,000 years. Nature $393,54-57$.

851

852 Scott, W.E., McCoy, W.D., Shroba, R.R., Rubin, M., 1983. Reinterpretation of the exposed

853 record of the last 2 cycles of Lake Bonneville, western United States. Quaternary Research 20,

$854 \quad 261-285$.

855

856 Seidenkrantz, M.S., Bornmalm, L., Johnsen, S.J., Knudsen, K.L., Kuijpers, A., Lauritzen, S.E.,

857 Leroy, S.A.G., Mergeai, I., Schweger, C., Van Vliet-Lanoe, B., 1996. Two-step deglaciation at

858 the oxygen isotope stage 6/5e transition: The Zeifen-Kattegat climate oscillation. Quaternary

859 Science Reviews 15, 63-75.

860

861 Shackleton, N.J., 1969. The last interglacial in the marine and terrestrial record. Proceedings of

862 the Royal Society of London, B. 174, 135-154.

863

864 Shackleton, N.J., 2000. The 100,000-year ice-age cycle identified and found to lag temperature,

865 carbon dioxide, and orbital eccentricity. Science 289, 1897-1902.

866

867 Shackleton, N.J., 2006. Formal Quaternary stratigraphy—What do we expect and need?

868 Quaternary Science Reviews 25, 3458-3462. 
870 Shackleton, N.J., Opdyke, N.D., 1973. Oxygen isotope and palaeomagnetic stratigraphy of

871 equatorial Pacific core V28-238: oxygen isotope temperatures and ice volumes on a 105 and 106

872 year scale. Quaternary Research 3, 39-55.

873

874 Shackleton, N.J., Berger, A., Peltier, W.R., 1990. An alternative astronomical calibration of the

875 Lower Pleistocene timescale based on ODP Site 677. Transactions of the Royal Society of

876 Edinburgh: Earth Sciences 81, 251-261.

877

878 Shackleton, N.J., Hall, M.A., Pate, D., 1995. Pliocene stable isotope stratigraphy of Site 846. in:

879 Pisias, N.G., Mayer, L.A., Janecek, T.R., Palmer-Julson, A., and van Andel, T.H. (Eds.),

880 Proceedings of the Ocean Drilling Program. Scientific Results 138, 337-355.

881

882 Shackleton, N.J., Sánchez-Goñi, M.F., Paillerc, D., Lancelot, Y., 2003, Marine Isotope Substage

883 5e and the Eemian Interglacial. Global and Planetary Change 36, 151-155.

884

885 Siddall, M., Chappell, J., Potter, E-K., 2007. Eustatic sea level during past interglacials. In

886 Sirocko, F. Claussen, M., Sánchez Goñi, M.F., Litt, T. (eds.), Climate of Past Interglacials.

887 Developments in Quaternary Science 7, 75-92.

889 Sirocko, F. Claussen, M., Sánchez Goñi, M.F., Litt, T. (eds.), 2007. Climate of Past Interglacials.

890 Amsterdam, Elsevier, Developments in Quaternary Science 7.

892 Skinner, L.C., Shackleton, N.J., 2005. An Atlantic lead over Pacific deep-water change across

893 Termination I: implications for the application of the marine isotope stage stratigraphy.

894 Quaternary Science Reviews 24, 571-580. 
896 Sun, Y., An, Z., 2005. Late Pliocene-Pleistocene changes in mass accumulation rates of eolian

897 deposits on the central Chinese Loess Plateau. Journal of Geophysical Research 110, D23101.

898

899 Sun, Y., Clemens, S.C., An, Z., Yu, Z. 2006. Astronomical timescale and palaeoclimatic

900 implication of stacked 3.6-Myr monsoon records from the Chinese Loess Plateau. Quaternary

901 Science Reviews 25, 33-48.

902

903 Teres, G., 1984. Time computations and Dionysius Exiguus. Journal for the history of

904 astronomy $15,177-188$.

905

906 Tzedakis, P. C., Andrieu, V., deBeaulieu, J.L., Crowhurst, S., Follieri, M., Hooghiemstra, H.,

907 Magri, D., Reille, M., Sadori, L., Shackleton, N.J., Wijmstra, T.A., 1997. Comparison of

908 terrestrial and marine records of changing climate of the last 500,000 years. Earth and Planetary

909 Science Letters 150, 171-176.

910

911 Tzedakis, P.C., Andrieu, V., deBeaulieu, J.L., Birks, H.J.B., Crowhurst, S., Follieri, M.,

912 Hooghiemstra, H., Magri, D., Reille, M., Sadori, L., Shackleton, N.J., Wijmstra, T.A., 2001.

913 Establishing a terrestrial chronological framework as a basis for biostratigraphical comparisons.

914 Quaternary Science Reviews 20, 1583-1592.

915

916 Tzedakis, P.C., Roucoux, K.H., DeAbreu, L., Shackleton, N.J., 2004. The duration of forest

917 stages in southern Europe and interglacial climate variability. Science 306, 2231-2235.

918

919 Tzedakis, P. C., Hooghiemstra, H., Pälike, H., 2006. The last 1.35 million years at Tenaghi

920 Philippon: revised chronostratigraphy and long-term vegetation trends. Quaternary Science

921 Reviews 25, 3416-3430. 
923 Tzedakis, P.C., Channell, J.E. T., Hodell, D.A., Kleiven, H.F., Skinner, L.C., 2012a. Determining

924 the natural length of the current interglacial. Nature Geoscience 5, 138-141.

926 Tzedakis, P.C., Wolff, E.W., Skinner, L.C., Brovkin, V., Hodell, D.A., McManus, J.F., Raynaud, 927 D., 2012b. Can we predict the duration of an interglacial? Climate of the Past 8, 1473-1485.

929 Vaks, A., Bar-Matthews, M., Matthews, A., Ayalon, A., Frumkin, A., 2010. Middle-Late

930 Quaternary paleoclimate of northern margins of the Saharan-Arabian Desert: reconstruction from 931 speleothems of Negev Desert, Israel. Quaternary Science Reviews 29, 2647-2662.

933 van Donk, J., 1976, ${ }^{18}$ O record of the Atlantic Ocean for the entire Pleistocene Epoch. in: Cline,

934 R.M., Hays, J.D. (Eds.), Investigation of Late Quaternary Paleoceanography and

935 Paleoclimatology. Geological Society of America Memoir 145, pp. 147-163.

937 Veres, D., Bazin, L., Landais, A., Kele, H.T.M., Lemieux-Dudon, B., Parrenin, F., Martinerie, P., 938 Blayo, E., Blunier, T., Capron, E., Chappellaz, J., Rasmussen, S.O., Severi, M., Svensson, A., 939 Vinther, B., Wolff, E.W., 2013. The Antarctic ice core chronology (AICC2012): an optimized 940 multi-parameter and multi-site dating approach for the last 120 thousand years. Climate of the $941 \quad$ Past 9, 1733-1748.

943 A. H. L. Voelker, A.H.L., Rodrigues, T., Billups, K., Oppo, D., McManus, J., Stein, R., Hefter, J.,

944 Grimalt, J.O., 2012. Variations in mid-latitude North Atlantic surface water properties during the 945 mid-Brunhes (MIS 9-14) and their implications for the thermohaline circulation. Climate of the 946 Past 6, 531-552. 
948 Walker, J.D., Geissman, J.W., Bowring, S.A., Babcock, L.E., compilers, 2012. Geologic Time

949 Scale v. 4.0. Geological Society of America, doi: 10.1130/2012.CTS004R3C.

950

951 Wang, Y., Cheng, H., Edwards, R.L., Kong, X., Shao, X., Chen, S., Wu, J., Jiang, X., Wang, X.,

952 An, Z., 2008. Millennial- and orbital-scale changes in the East Asian monsoon over the past

953224,000 years. Nature 451, 1090-1093.

954

955 Westaway, R., 2010. Improved age constraint for pre- and post-Anglian temperate-stage deposits

956 in north Norfolk, UK, from analysis of serine decomposition in Bithynia opercula. Journal of

957 Quaternary Science 25, 715-723.

958

959 Westaway, R., 2011. A re-evaluation of the timing of the earliest reported human occupation of

960 Britain: the age of the sediments at Happisburgh, eastern England. Proceedings of the Geologists'

961 Association 122, 383-396.

962

963 Wright, I.C., McGlone, M.S., Nelson, C.S., Pillans, B.J., 1995. An integrated latest Quaternary

964 (Stage 3 to present) paleoclimatic and paleoceanographic record from offshore northern New

965 Zealand. Quaternary Research 44, 283-293.

966

967 Wright, J.D., Sheridan, R.E., Miller, K.G., Uptegrove, J., Cramer, B.S., Browning, J.V., 2009.

968 Late Pleistocene sea level on the New Jersey margin: Implications to eustasy and deep-sea

969 temperature. Global and Planetary Change 66, 93-99.

970

971 Wu, G., You, T., Thompson, L.G., Li, Z., 2009. Microparticle record in the Guliya ice core and

972 its comparison with polar records since the last interglacial. Chinese Science Bulletin 49, 607-

973611. 
975 Yelovicheva, Ya.K. 2006. Late Pleistocene interglacial and glacial deposits in Belarus. In

976 Johansson, P., Lunkka, J.-P., Sarala, P. (eds.), 2006. Late Pleistocene glacigenic

977 deposits in the central part of the Scandinavian ice sheet: Abstracts. The INQUA Peribaltic

978 Group Field Symposium in Finland, September 11-15, 2006. Geological Survey of

979 Finland, Rovaniemi, p. 52.

980

981 Zazo, C., 1999. Interglacial sea levels. Quaternary International 55, 101-113.

982

983 
Table 1. Geochronologic intervals and their stratigraphic equivalents, with examples

\begin{tabular}{ccccc} 
& & Global chrono- & Climato- & Climato- \\
Geochronologic & Chronostratigraphic & stratigraphic & stratigraphic regional & stratigraphic marine \\
(time) interval ${ }^{1}$ & (time-rock) interval ${ }^{1}$ & example $^{2}$ & continental example $^{2}$ & isotopic example $^{2}$ \\
Period & System & Quaternary & \\
Epoch & Series & Pleistocene & \\
Age & Stage & Calabrian & & MIS 7 \\
Subage & Substage & & Wisconsin & MIS 7b \\
\hline
\end{tabular}

${ }^{1}$ For the significance of this distinction, see Fig. 5 and Section 5.2, and more generally Salvador (1994).

${ }^{2}$ Note that these examples are not time-equivalents (e.g., Wisconsin is not Calabrian, and Mankato is not $7 b)$.

${ }^{3}$ Cita et al. (2012). 
Table 2. First designations of lettered substages

\begin{tabular}{|c|c|c|c|}
\hline Substage & Earliest known use $^{1}$ & MIS literature cited & Record $^{2}$ \\
\hline $2 \mathrm{a}$ to $2 \mathrm{~h}$ & Yelovicheva, $2006^{3}$ & None & Non-marine sediments \\
\hline $3 a$ and $3 b$ & Wright et al. 1995 & None & Marine $\mathrm{CaCO}_{3}$ \\
\hline $3 \mathrm{c}$ & Wu et al., 2004 & None & $\delta^{18} \mathrm{O}$ of Tibetan ice \\
\hline $3 \mathrm{~d}$ and $3 \mathrm{e}$ & Yelovicheva, 2006 & None & Non-marine sediments \\
\hline $4 \mathrm{a}$ to $4 \mathrm{c}$ & Yelovicheva, 2006 & None & Non-marine sediments \\
\hline $5 \mathrm{a}$ to $5 \mathrm{e}$ & Shackleton, 1969 & Emiliani (1961) & Marine $\delta^{18} \mathrm{O}$ \\
\hline $6 a$ to $6 \mathrm{e}$ & Sun and An, 2005 & None & Loess \\
\hline $6 f$ & Kawamura et al. 2007 & Tzedakis et al. 2004 & Dome Fuji $\delta^{18} \mathrm{O}$ \\
\hline \multirow[t]{2}{*}{$7 \mathrm{a}, 7 \mathrm{~b}, 7 \mathrm{c}$} & Ninkovich and Shackleton, 1977 & Emiliani 1955, 1966; & Marine $\delta^{18} \mathrm{O}$ \\
\hline & & Shackleton 1969 & \\
\hline \multirow[t]{3}{*}{$7 d$} & Prokopenko et al., 2001; & Imbrie et al. 1984 & Lacustrine silica \\
\hline & Khursevich et al., 2001 & None & Lacustrine silica \\
\hline & Forsström, 2001 & None & Vostok $\delta \mathrm{D}$ \\
\hline \multirow[t]{3}{*}{$7 \mathrm{e}$} & Tzedakis et al., 1997 & Imbrie et al. (1984); & Marine $\delta^{18} \mathrm{O}$ \\
\hline & & \multicolumn{2}{|l|}{ Prell et al. (1986); } \\
\hline & & \multicolumn{2}{|l|}{ Martinson et al. (1987) } \\
\hline $8 \mathrm{a}$ to $8 \mathrm{c}$ & None found & - & - \\
\hline $9 a, 9 b, 9 c$ & Bussell and Pillans, 1992 & Imbrie et al. 1984 & Marine $\delta^{18} \mathrm{O}$ \\
\hline \multirow[t]{2}{*}{$9 d$} & Prokopenko et al., 2001; & Imbrie et al. 1984 & Lacustrine silica \\
\hline & Khursevich et al., 2001 & None & Lacustrine silica \\
\hline \multirow[t]{3}{*}{$9 \mathrm{e}$} & Tzedakis et al., 1997 & Imbrie et al. (1984); & Marine $\delta^{18} \mathrm{O}$ \\
\hline & & \multicolumn{2}{|l|}{ Prell et al. (1986); } \\
\hline & & \multicolumn{2}{|l|}{ Martinson et al. (1987) } \\
\hline
\end{tabular}




\begin{tabular}{|c|c|c|c|}
\hline $10 \mathrm{a}, 10 \mathrm{~b}, 10 \mathrm{c}$ & Lundberg and MacFarlane, 2007 & None & Cave deposits \\
\hline \multirow[t]{3}{*}{$11 \mathrm{a}$ and $11 \mathrm{c}$} & Tzedakis et al., 1997, 2001 & Imbrie et al. (1984); & Marine $\delta^{18} \mathrm{O}$ \\
\hline & & Prell et al. (1986); & \\
\hline & & Martinson et al. (1987) & \\
\hline \multirow[t]{2}{*}{$11 b$} & Ashton et al., $2008^{4}$ & Tzedakis et al. 2001; & Marine $\delta^{18} \mathrm{O}$ \\
\hline & & Prokopenko et al. 2001 & \\
\hline $11 d$ & Ashton, $2010^{4}$ & & \\
\hline $11 \mathrm{e}$ & Prokopenko et al., 2001 & Imbrie et al. 1984 & Lacustrine silica \\
\hline $12 \mathrm{a}, 12 \mathrm{c}, 12 \mathrm{e}$ & Sun and An, 2005 & None & Loess \\
\hline $12 b$ & Voelker et al., 2010 & None & Marine $\delta^{18} \mathrm{O}$ \\
\hline $13 \mathrm{a}$ & Westaway, 2010 & None & Bithynia ala/ser ${ }^{5}$ \\
\hline $13 c$ & Voelker et al. 2010 & None & Marine $\delta^{18} \mathrm{O}$ \\
\hline $13 \mathrm{~b}, 13 \mathrm{~d}, 13 \mathrm{e}$ & None found & - & - \\
\hline $14 \mathrm{a}, 14 \mathrm{~b}, 14 \mathrm{c}$ & None found & - & - \\
\hline $15 \mathrm{a}, 15 \mathrm{~b}, 15 \mathrm{c}, 15 \mathrm{~d}, 15 \mathrm{e}$ & Khursevich et al., 2001 & None & Lacustrine silica \\
\hline $16 a, 16 c$ & Sun and An, 2005 & None & \\
\hline $16 b, 16 d$ & None found & - & - \\
\hline $17 \mathrm{a}, 17 \mathrm{~b}, 17 \mathrm{c}, 17 \mathrm{~d}, 17 \mathrm{e}$ & None found & - & - \\
\hline $18 \mathrm{a}, 18 \mathrm{~b}, 18 \mathrm{c}$ & None found & - & - \\
\hline $19 \mathrm{a}, 19 \mathrm{~b}, 19 \mathrm{~d}, 19 \mathrm{e}$ & None found & - & - \\
\hline $19 \mathrm{c}$ & Tzedakis et al.. 2012a; & None & Marine $\delta^{18} \mathrm{O}$ \\
\hline & Tzedakis et al., 2012b & None & EPICA C $\delta D$ \\
\hline
\end{tabular}

20a to $27 \mathrm{e}$ None found

${ }^{1}$ This list shows the earliest use reported in searches of Web of Science, with earlier additions from the authors' knowledge. 
${ }^{2}$ The record used to define the substage, which may not have been the kind of record studied.

${ }^{3}$ Yelovicheva (2006) explicitly labelled her eight substages as "MIS". Murari et al. (2014) identified five monsoonal Himalayan-Tibetan stages (MOHITS) from 2A to 2E correlative with MIS 2, and Dortch et al. (2013) identified six semi-arid western Himalayan-Tibetan stages (SWHTS) from 2A to 2F correlative with MIS 2.

${ }^{4}$ Jahns et al. (1998) referred to "Pollen subzones" $11 \mathrm{~b}$ and 11d in "oxygen isotope stage 11", but they did not explicitly refer to substages designated $11 \mathrm{~b}$ and $11 \mathrm{~d}$.

${ }^{5}$ Ratio of the amino acids alanine and serine in opercula of the freshwater gastropod Bithynia. 
984 Fig. 1. Six different published styles of dividing Pleistocene time series, with the middle four

985 from founding papers in the field of marine isotope stratigraphy discussed in Sections 2.2 and 2.3.

986 The curve shown, and all of the letters and numbers, are arbitrary creations to illustrate the

987 various schemes: "6" and "8" only suggest even numbers assigned to glacial periods; "7" only

988 suggests odd numbers assigned to interglacials; etc. Dashed lines are boundaries between

989 intervals; brackets identify short intervals; solid lines point to events of very short duration. 
Style of Arrhenius (1952)

Stages and substages

A

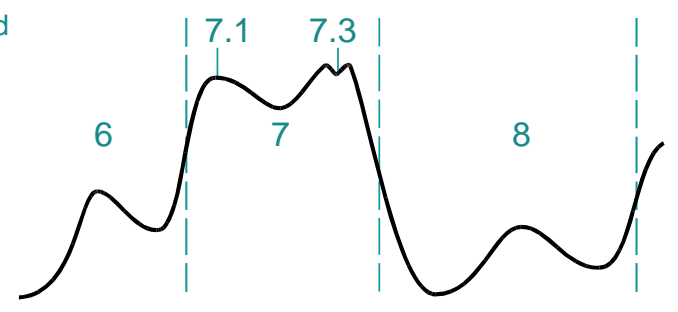

Style of Emiliani $(1955,1961)$ and Shackleton (1969) Stages and
substages

B
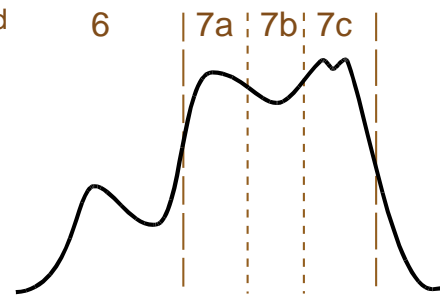

8

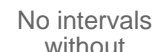
without
designation

Style of Prell et al. (1986)

Events of discernible duration, except at stage boundaries C

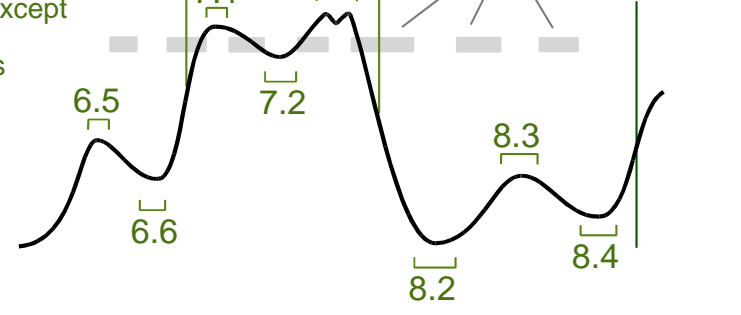

Style of Pisias et al. (1984)

Events of discernible duration

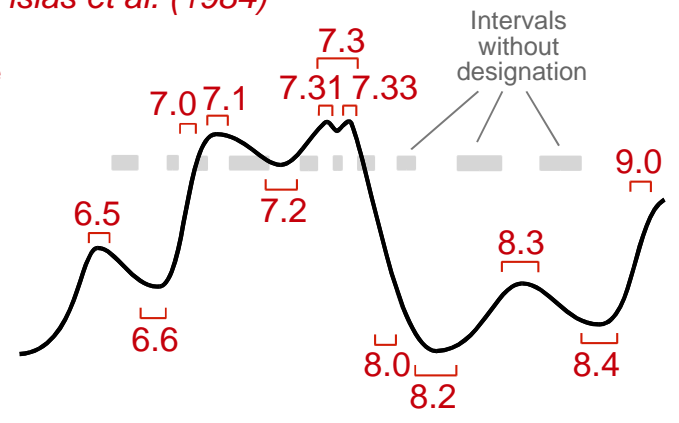

Style of Martinson et al. (1987)

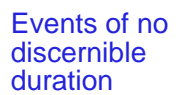

Events of no
discernible

duration $7.31 \mid 7.33$

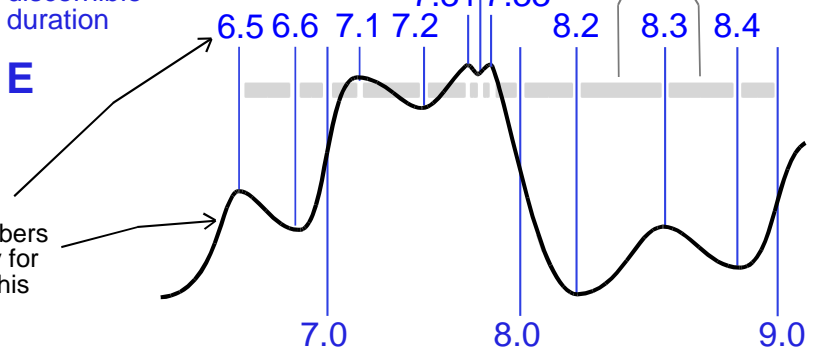

Style of Wang et al. (2008)

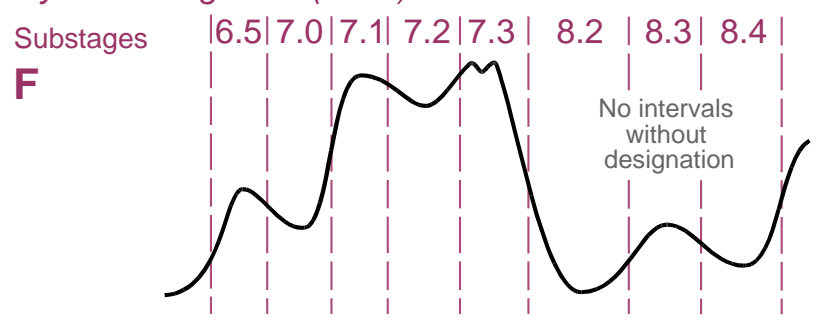


993 Fig. 2. Some examples of the contradictory designations of isotope substages used in the

994 published literature from 1997 to 2015, as discussed in Section 3. Each gray box indicates

995 assignments from one system of one publication. Red highlights the earliest substage of MIS 6,

996 for which five different designations have been used in the literature. 


$\begin{array}{cccccc}5 c & & 7 a 7 c & 7 e & 9 & 15 a 15 c 15 e \\ 5 d & 6 & 7 b & 7 d & 8 & \end{array}$

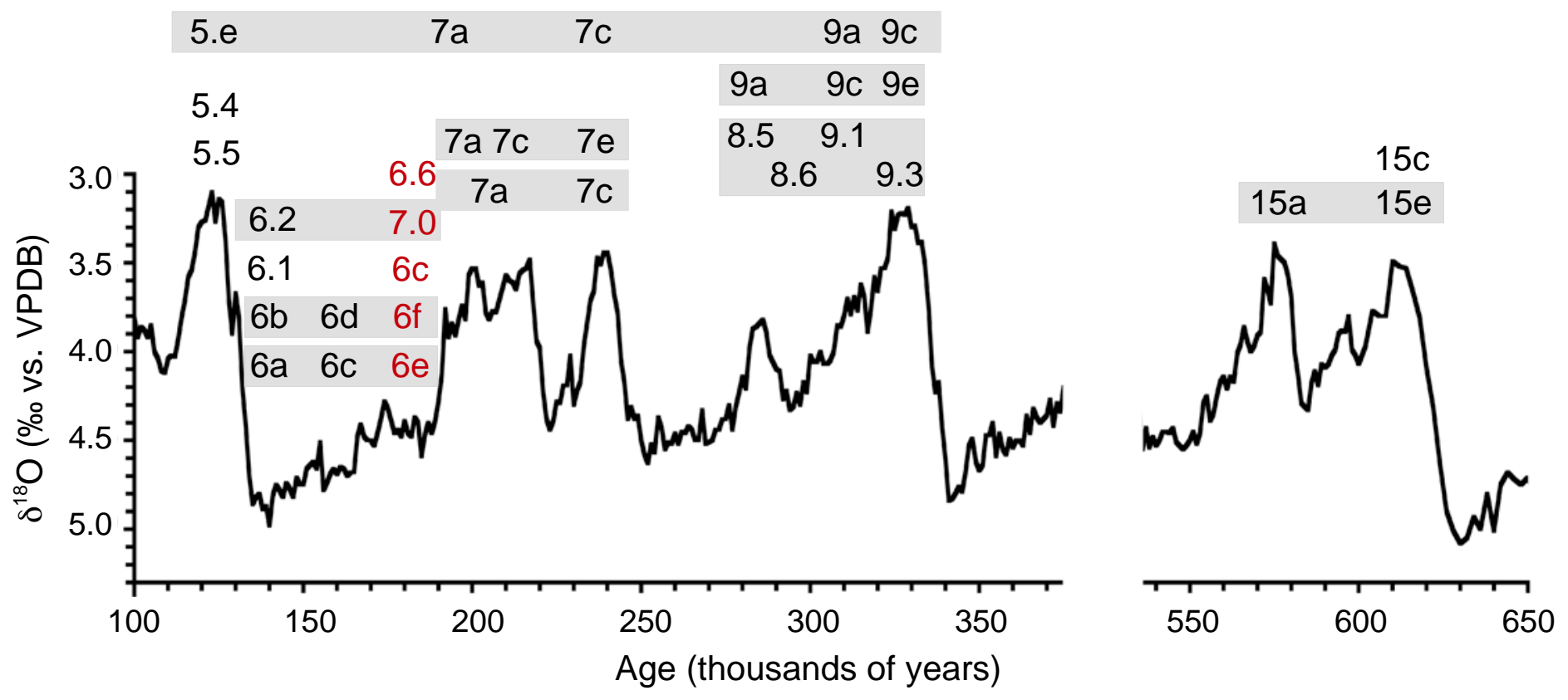


999 Fig. 3. Proposed scheme of marine isotope substages for the last 1.0 million years, defined

1000 relative to the LR04 stack of marine benthic foraminiferal $\delta^{18} \mathrm{O}$ data of Lisiecki and Raymo

1001 (2005). Horizontal bars indicate the length of each substage. Many substages come from the

1002 sources listed in Table 1. However, many papers only labelled a peak or trough on a time-series

1003 diagram, with no indication of boundaries, and some papers only named the substage(s) in the

1004 text with no illustrative time series. The stages are taken from Shackleton and Opdyke (1973),

1005 Ruddiman et al. (1989), and Lisiecki and Raymo (2005). Roman numerals indicate terminations

1006 (Broecker and van Donk, 1970) or transitions (Jouzel et al., 2007) from glacial to interglacial

1007 stages, with Termination IIIA from Cheng et al. (2009). Six other time-series of data are shown

1008 to illustrate the relevance of the substages in those data. Criteria used in constructing this scheme

1009 are discussed in Section 4.

1010

1011 
Thousands of years B.P. 
1012

1013 Fig. 4. Euler diagram showing different kinds of time-series data and the kinds of stages that

1014 would be identified from them, as discussed in Section 5.1.

\section{5}

1016 
Isotope stages

$\delta D$ data from ice cores

$\delta^{15} \mathrm{~N}$ data from middens

$\delta^{18} \mathrm{C}$ data from stalagmites

${ }^{10} \mathrm{Be}$ data from sediment cores

\section{Marine isotope stages}

$\delta^{34} S$ data from

marine sediment cores

$\delta^{15} \mathrm{~N}$ data from

marine sediment cores

Marine oxygen isotope stages

$\delta^{18} \mathrm{O}$ data from

marine sediment cores

$\delta^{18} \mathrm{O}$ data from stalagmites

Oxygen isotope stages

Dust data from ice cores

Pollen data from lacustrine sediment cores

Particle-size data from sediment cores

Compositional data from sediment cores Ice-rafted-debris data from sediment cores 
1018 Fig. 5. Three hypothetical sets of time series data illustrating chronological errors possible in 1019 identifying stages (blue) or events (red) from time-series data of different kinds, as discussed in

1020 Section 5.2. A and B combine to illustrate how differential time lags can cause faulty correlations

1021 in time of both stages and events; B and C combine to illustrate how difference in latitude or

1022 altitude can cause faulty correlations in time of stage boundaries. Comparison of B and C also

1023 illustrates why the dating of terminations may be more disputed than the dating of maxima or

1024 minima in some isotopic curves, supporting the preference of Prell et al. (1986) for use of events,

1025 rather than stages, for correlation to absolute time scales. The figure illustrates some aspects of

1026 the argument by Gibbard (2014) that "isotope stratigraphy is not strictly a chronostratigraphy". 1027 


\section{Stages: $n \quad n+1 \quad n+2 \quad n+3$}

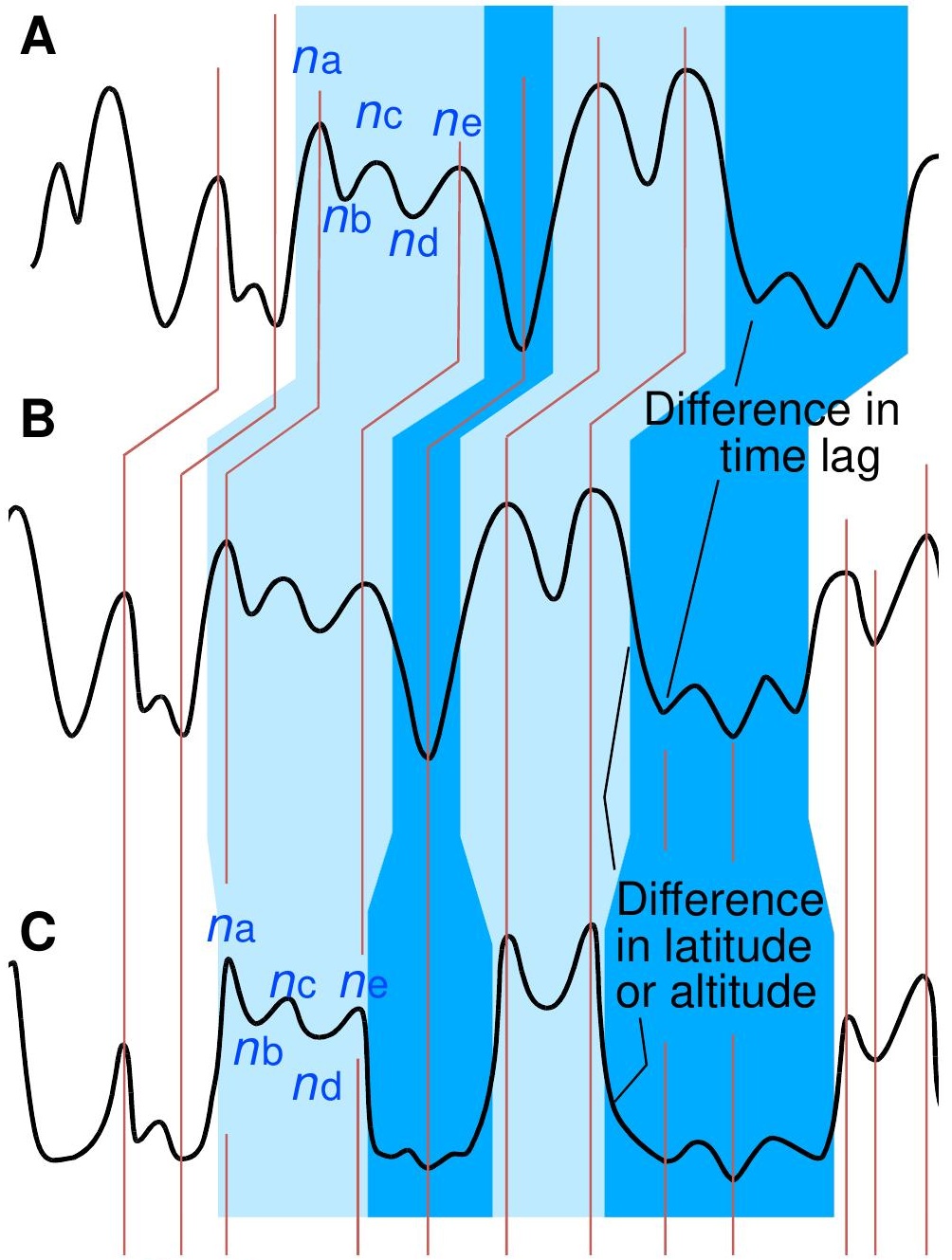

Events 